\begin{tabular}{|c|c|c|c|}
\hline $\begin{array}{c}\text { RESEARCH } \\
\text { ARTICLE }\end{array}$ & $\begin{array}{r}\text { ADVANCE RESEARCH JOURNAL } \\
\text { Volume } 7 \mid \text { Issue } 1 \mid \text { June, } 2016 \mid 91-97\end{array}$ & $\begin{array}{l}\text { OF SOCIAL SCIENCE } \\
\text { e ISSN-2231-6418 }\end{array}$ & \\
\hline $0=$ & DOI: 10.15740/HAS/ARJSS/7.1/91-97 & Visit us : www.researchjournal.co.in & \\
\hline
\end{tabular}

\title{
Status of rural women in the farm and non-farm activities as well as in the household's decision making process in Gurdaspur district of Punjab
}

\author{
P.K. Ghuman*, Bhupinder Singh ${ }^{1}$, R.S. Chhina ${ }^{1}$ and Bikramjit Singh ${ }^{1}$ \\ Krishi Vigyan Kendra, GURDASPUR (PUNJAB) INDIA \\ ${ }^{1}$ Institute of Agriculture, Regional Station (P. A.U.), GURDASPUR (PUNJAB) INDIA
}

\section{ARTICLE INFO :}

$\begin{array}{lll}\text { Received } & : & 18.03 .2016 \\ \text { Revised } & : & 16.04 .2016 \\ \text { Accepted } & : & 17.05 .2016\end{array}$

KEY WORDS :

Rural women, Farm and non-farm, Household's decision

HOW TO CITE THIS ARTICLE :

Ghuman, P.K., Singh, Bhupinder, Chhina, R.S. and Singh, Bikramjit (2016). Status of rural women in the farm and non-farm activities as well as in the household's decision making process in Gurdaspur district of Punjab. Adv. Res. J. Soc. Sci., 7 (1) : 91-97, DOI: 10.15740/HAS/ ARJSS/7.1/91-97.

\section{ABSTRACT}

The present study entitled, "Status of rural women in the farm and non- farm activities as well as in the household's decision making process in Gurdaspur district of Punjab" was conducted with the specific objectives, namely to examine the involvement of rural women in farm and non-farm activities and to quantify the role of different factors in the decision making process in the family during 2014-15 in the KVK, Gurdaspur's adopted villages in the district. A total of 100 rural households consisting of 70 farm households, spread over small, medium and large size categories and 30 agricultural labour households were selected at random. Survey method was applied for the collection of primary data. To achieve the objective of the study, various statistical tools like averages, percentages, etc. were used. It has been observed in the study that the female literacy rate was lower than their male counterparts in all the household categories in the study area. Women in the villages have been found to be performing in both the domestic as well as farm activities. In Punjab, farm women, usually, do not work in the fields but they do help in tending of cattle and handling of milk and milk products. However, women of agricultural labour families do work in the fields and also in the farmhouses in the village itself or in the houses of nearby towns/cities as maid servants. The study showed that rural women in the sample villages worked over 4600 to 5700 hours during the year on small farm, medium and large households and agricultural labour households over 5433 hours. Nearly one third of the farm women's and 18.93 per cent of the agricultural labour household women's time was used on farm related activities like crop production, cattle tending, mulching and processing, sale of milk, cooking and serving food to the labour, handling and storage of crop produce and other work including work in nearby houses and factories. And, the remaining two third of farm women's and 81.28 per cent of farm labour women's' time was used on non-farm activities such as cooking and serving food to the family, cleaning of the house, utensils, sending children to the school, washing clothes, tailoring, knitting and dari making, going to fairs and other social occasions, visiting relatives, teaching children and some time for recreation activities like viewing T.V. etc. The rural women thus, worked for 12-16 hours a day and performed numerous jobs during the period. The study clearly brought about that, in the farm activities involving financial matters, women had very little say in the family, and they were found to have 